\title{
ICT in EFL Teaching and Learning: A Systematic Literature Review
}

\author{
Kashif Ali Sabiri \\ University of Tampere, Finland \\ ORCID: 0000-0002-8663-579X
}

Received: 31 Oct 2019

Accepted: 17 Dec 2019

Published: 26 Dec 2019

\begin{abstract}
This literature review focuses the research conducted on Information and Communication Technology in English as a Foreign Language Teaching and Learning. It reviews various aspects of ICT integration, ICT tools, barriers and challenges to ICT integration, teachers' perceptions and views about ICT and advantages and benefits of ICT integration in education. The factors effecting pre-service and in-service teachers and student teachers' perceptions, views and confidence about ICT integration are also discussed and analyzed. This review further discusses the gaps in the studies and establishes a theoretical background for further studies specifically in Oman.
\end{abstract}

Keywords: ICT, EFL teaching, barriers and solutions of ICT use, teachers' attitudes and beliefs on ICT use

\section{INTRODUCTION}

Information and communication technology has taken over teaching and learning around the globe (Selinger, 2001c). ICT tools and techniques are used to enhance teaching and learning opportunities more specifically remote learning resources. ICT integration prepares learners for real-life situations (Lowther et al., 2008, Weert \& Tatnall, 2005). The technological developments have introduced an information revolution which has innovated the life and living of the people (Pachler, 2001, p. 15). The integration of ICT has transformed the teaching environment into learner-centered (Castro Sánchez \& Alemán, 2011).

This review aims at identifying well documented sources from published work. Various articles used in review discuss the following research questions focusing specifically Omani higher education system:

1. How far ICT is integrated in EFL teacher training programs

2. What are various barriers and challenges in ICT integration

3. What are the advantages and benefits of ICT integration

A comprehensive literature review has been conducted to analyze the theories and research methodologies investigating ICT integration into EFL teaching and learning. Most of the studies under review have employed three major methodologies: qualitative, quantitative and mixed. Different conceptual and theoretical frameworks have been employed in the studies under review. The respondents of all these studies are mostly teachers and learners. These respondents come from all levels of educational establishments such as school, college and 
university. Various areas of teaching and learning are discussed in these studies like curriculum, teacher training and subject-related studies.

The review covers the studies at three levels: global, regional and local. Barriers and challenges to integrating ICT in Omani education system have been discussed by most of the researchers. The main areas of ICT integration are EFL and teacher-training. Learners' motivation is another highly important factor that contributes positively towards ICT integration. All these studies cover major areas of ICT integration yet there are certain gaps. The paper concludes suggesting various recommendations.

\section{METHODOLOGY FOR THE LITERATURE REVIEW}

Literature review is conducted for various purposes by researchers. It helps researcher identify various potential areas for relevant research and various gaps that ask for further research. In a thorough literature review, the reviewer compares previous findings to understand the methodologies employed. An effective review is the base for advancing research and knowledge. It helps in developing theoretical study of the research area.

A structured approach suggested by Webster and Watson has been adopted to search, select, scan, read and analyze the texts related to ICT integration.

The samples of this study are searched using the following search sites;

https://doaj.org/

https://zenodo.org/

https://www.omicsonline.org/free-journals.php

http://journaldatabase.info/academic/list/E.html

http://journals.sagepub.com/home/sgo

https://scholar.google.com/

http://e-flt.nus.edu.sg/index.html

https://www.google.com/

The key words used are; ICT integration, EFL, Teacher Training Program, Oman. The searches are restricted to relevant keywords and data available in English language only. The data used are published articles and books. A total of 23 published works have been used for review. In the first stage, the articles have been selected after a scanning of the abstract and introduction of each and every work in review. A detailed study of all the articles and books has helped in categorizing the works which address the research questions. All the works in review are published in the last two decades that is between 2003 and 2017.

\section{MAPPING OF THE WORKS IN REVIEW \& AREAS OF DISCUSSION}

All the 23 papers are mapped into 3 major and 2 sub-categories for review and discussion.

4 papers discuss the challenges and barriers of ICT integration; 10 papers focus the impact of ICT, teachers' beliefs and perceptions about ICT integration; 7 papers spot light on the advantages and benefits of using ICT in teaching and learning. One of the seven papers shows a comparative study of ICT integration among various Arab states. This paper explains some 
research areas like measuring ICT integration, current condition of ICT integration in Arab states, infrastructure to support ICT and ICT in curriculum. And, two papers are literature reviews which discuss the ICT integration into curriculum, teachers' beliefs about ICT integration and some suggestions for future EFL teachers to adapt ICT positively.

\section{AREAS OF DISCIPLINE}

The works in review cover seven major disciplines that link ICT with education. 5 papers discuss teacher education; 6 papers are about EFL teaching and learning; 4 papers explain research about school teachers and another 5 papers discuss University education. There are three more papers and each of them discusses Science Education, CALL and Blended Learning respectively.

\section{RESEARCH METHODOLOGY AND DESIGN}

This paper discusses various research methodologies and designs employed in all papers included for literature review. 8 papers have used a mixed of qualitative and quantitative methodology; in 3 papers, the researchers have employed quantitative methodology whereas in 7 papers, the researchers have conducted research using qualitative methodology.

In 7 papers, content analysis study design has been used to conduct the research. Survey analysis has been the study design for 5 different research papers whereas only one paper has employed cluster analysis design. 1 researcher has conducted the research using descriptive-interpretive approach and another one has employed hypothetical study. Still, another one study has been conducted as a case study. Two papers have used questionnaire and interview data collection tools. There is one paper which has employed questionnaire method of data collection and another one has used interview to collect data for result analysis.

\section{THE PARTICIPANTS / POPULATION OF THE STUDIES}

The participants and population in all papers are from various levels of educational institutions belonging to different cultures. Majority of the respondents in review papers are EFL school teachers and university lecturers. Some researchers have conducted their research with students also. Very few researchers have used policy makers and curriculum developers as their study population. Almost all the researchers have given due importance to ethical issues while conducting their research.

\section{IMPACT OF ICT AND TEACHERS' PERCEPTIONS ABOUT ICT}

According to Albirini (2006), ICT has three kinds of impact namely affect, cognition and behavior. The use of ICT is likely to help learners for future high-tech workplace although this implementation is relatively slower in Asian countries (Huong Thi Bao Dinh, 2015). The role of teachers in using ICT depends on their willingness (BECTA, 2004; Ertmer et al., 1999; Groff \& Mouza, 2008; Hew \& Brush, 2007; Mumtaz, 2000; Zhao et al., 2002) whereas according to Huong Thi Bao Dinh (2015) it is teachers' beliefs and attitudes as well as knowledge and skills that are the vital factor in employing ICT in teaching EFL (Saye, 1998). ICT makes lessons more interesting and motivating for the learners. It facilitates communication between teachers and learners (Huong Thi Bao Dinh, 2015). Houng's study consolidated the idea that EFL teachers' preknowledge in the $2^{\text {nd }}$ decade of the $20^{\text {th }}$ century as compared to their knowledge a decade ago, helped them integrate ICT with a positive attitude and there remains less need to convince EFL 
teachers for using ICT rather, we need to find ways for applying their knowledge in ICT integration.

Steiner and Mendelovitch (2016) found that science teachers find ICT useful in their teaching especially in promoting students' concentration and active learning. ICT integration, further, caters the needs of all students simultaneously as these tools can be adjusted according to the pace, ability level and needs of the learners. But, according to these researchers, they need to use these tools on regular basis. These two researchers have further found that most of the science teachers use ICT as an aide for improving their teaching. There is a need to include ICT for improving pedagogical paradigms (Graham et al., 2009; Guzey \& Roehrig, 2009; McCrory, 2008). Most of the teachers use ICT tools in limited ways just to concrete their certain illustrations and simulations. This study wants teachers to use ICT for guiding and supporting the learners. Steiner and Mendelovitch (2016) and Huong Thi Bao Dinh (2015) found that most of the teachers support ICT integration because it promotes relevance and simulating learning. It is very useful in establishing connections between teacher and students. The inclusion of audiovisual aids has improved teaching and learning. The concept of virtual learning for science students is time-saving and more reliable, found Steiner and Mendelovitch (2016). This study discusses three approaches to ICT integration and these are ICT use as a frontal teaching tool, integration of ICT with frontal instruction and ICT as the focus of pedagogy.

Al-Senaidi and Gawande (2013) found that online learning at Sultan Qaboos University, Oman has increased noticeably and the university has successfully integrated ICT in the form of Moodle and WebCT supporting eOman initiative in 2006. The Oman ministry of education has successfully launched virtual classroom and self-learning system through the implementation of e-learning. This research focused three areas: institutional strategic implementation of the elearning system, faculty members and e-learning and the impact of e-learning on students. Before this study, almost all the research in SQU focused only faculty. The researchers found that the faculty used ICT sometimes and not often and this integration was limited to web browsing, search engines and word processing. The major hurdles in integrating ICT, according to this study were lack of confidence and lack of skills.

Huong Thi Bao Dinh (2015) found that EFL teachers used ICT in general for power point and word processor and sometimes as language dictionaries and online videos to support their teaching. The use of ICT as tutorials and drills as well as web-based activities was very low. Another problem they noticed was that most of the faculty had never used any online communication tool or channel to assist their teaching and students' learning, though they used ICT for email communication. Further, according to Huong Thi Bao Dinh, most of the EFL teachers had good knowledge to adapt ICT tools according to their need but they were very selective in using certain applications (Jordan, 2011, p. 16). Some of the study participants also told that they had to use ICT as it was made mandatory was the university. Thus, the findings conclude that teachers' ICT integration was both optional as well as compulsory. Another serious problem noticed was the possession of ICT. The researchers found that teachers had the major possession whereas the leaners had very limited access to ICT tools in the university. Unlike the previous research (BECTA, 2004; Ertmer et al., 1999; Groff \& Mouza, 2008; Hew \& Brush, 2007; Mumtaz, 2000; Zhao et al., 2002) which said that teacher's role is more important in ICT use, this study found that the teacher is the most important factor in integrating ICT in teaching. This study further found that EFL teachers' beliefs in the benefits of ICT in their classroom instruction are different from Lam's (2000) and Ma and Yuen's (2002) findings, but are similar to Dinh's (2009), Dang's (2014), Li and Ni's (2011), Park and Son's (2009) and Saglam and Sert's (2012) studies. This study also conceptualized that teachers' Technological Pedagogical Content Knowledge (TPACK) had a positive correlation with their use of ICT. Huong Thi Bao Dinh (2015) also found 
that the TPACK was more important to conceptualize the teachers' skills and knowledge and gave less importance to the technical competences of the teachers.

Md. Shah and Empungan (2015) state that attitudes toward ICT usage reflect the general feelings of teachers and learners towards ICT and related activities (Smith, Caputi, \& Rawstone, 2000; Abedalaziz, Sharir \& Chin, 2013). The researchers quote Joseph (2013) who believes that teachers' must be encouraged to use ICT in their classes. Like certain previous studies, this study also concluded that teachers had positive attitudes towards ICT integration. There is a need to link ICT use with teachers' talent as well as choice of use.

Gilakjani (2012) found that an easy access to ICT in teaching develops teachers' confidence by providing them more opportunities (Hogaboam-Gray \& Hannay, 1999). Before making teachers use ICT, there is the need to convince as well as properly train the teachers for this. The researcher believes that students are the primary focus for the teachers and the teachers must be fully aware of the impact of ICT on students' learning (Higgins \& Moseley, 2001). Abbas supports Lam (2002) that teachers use ICT as an instructional tool and not only for drill and practice, to enhance students' learning. Some teachers associated ICT use with the integration of material required to explain cultural issues.

Abbas agrees with Saye (1998) on that teachers' beliefs determine the level and way of ICT integration. Abbas advocates Vannatta and Fordham (2004) that teachers' training and willingness to change define their use of ICT in class room. Abbas finds a need to include ICT impact in Shulham's (1987) definition of curricular knowledge. He argues that teachers must have proper knowledge of ICT so that they can adapt the ICT tools to meet the needs of their lessons. He also shows his concern when he finds that Cuban (2001); Ertmer, (2005); Hew and Brush (2007) have highlighted a serious deficiency of ICT integration despite increasing number of technologies (Vrasidas \& Mclsaac, 2001). He attributes this drawback to irrelevant or insufficient teacher-training programs for pre-service teachers. His research asks for welldesigned and technology-oriented teacher training programs (Hasselbring et al., 2000; Howard, McGee, Schwartz, \& Purcell, 2000; Vannatta \& Beyerbach, 2000). His research concluded that teacher preparation programs need to meet the needs and demands of the future and this is likely to strengthen the link between technology integration and educational reforms.

Qureshi, Nawaz and Khan in their research conducted in Pakistan found users' perceptions as the key factor in determining teachers' beliefs and attitudes about ICT integration. Usersatisfaction depends upon their opinions about educational technologies and use practices. Yadollahi and Rahimi (2011) used the chi square test to find out teachers' perceptions and impact of ICT in teaching and learning. This study established a relationship between language skills being taught and the type of ICT toll being used for that purpose. Majority of the teachers used ICT tools for teaching oral skills (Yang \& Huang, 2008). This study found a correlation between technology use and the years of the experience of the teacher but didn't find any connection between gender and ICT use. The experienced teachers are less likely to integrate ICT whereas young teachers are more willing to using these tools Prensky (2001). The teachers having their personal computers were more reluctant to integrating ICT. The study further found a clash between the existing pedagogical environment and the need for ICT integration particularly in Iran. This clash was attributed to the outdated EFL curriculum which needed immediate revisions. Another important factor perceived by EFL teachers in ICT inclusion is the time constraint as the teachers have to cover the syllabus on time. This retards them in integrating ICT skillfully and for various skills. The teachers in Iran had very limited access to internet and the researchers recommended developing teachers' awareness about latest ICT 
tools, professional development and the usefulness of ICT tools in teaching different language skills.

Kreutz and Rhodin (2015) studied ICT impact on learners. They found that computers make learning exciting by developing learners' curiosity and motivation; developing independent and personalized learning (Jedeskogs, 1998; Frydrychova Klimova, \& Poulova, 2014). The study further found that learners get motivation both from teachers and parents (Dörnyei, 2001; Pintrich et al., 1991; Willian \& Burden, 1997). They found that ICT facilitates learning through differentiation and individualization (Volman, Admiraal, \& ten Dam, 2011). Students found learning a fun when the teachers use ICT but they enjoyed learning more when they get independence in the use of ICT. Their study concludes that it is students' motivation which triggers ICT integration.

Kilickaya and Seferoglu found that CALL-based materials developed students' excitement when they were taught writing through online blogs and wikis. This motivated the learners to take active part in learning processes. Various CALL-based tools such as Listening websites (Elllo and esl-lab), Videos (YouTube), Digital Story-telling Dokeos, Blogs and Wikis (Blogger and PBworks), WiziQ, Concordance (COCA and Jukuu), Online Dictionaries (Cambridge, Macmillan and Longman Dictionary of Contemporary English), Authoring tools (Hot Potatoes, QuizFaber and QuizStar) and PowerPoint as a presentation and authoring tool, were employed by pre-service teachers to enhance their learning. Some of the teachers used these online materials for exams. These tools helped learners improve their language skills. The only problem in ICT integration was the learners' limited access to these tools. The learners were encouraged to improve their ICT skills through continuous online learning courses. Alev (2013) found three forms of attitudes towards ICT integration: anxiety, appreciation and interest, and usefulness. His study observed a feeling of uneasiness about ICT among student-teachers and this led to fear of technology. But, the constant use of technology developed strong interest in ICT use and found it a valuable resource for enhancing teaching and learning, though for a very small number of studentteachers ICT use was wastage of teaching and learning time. Continuous teacher training programs and peer observations motivated student-teachers for integrating ICT in their teaching.

\section{CHALLENGES AND BARRIERS TO ICT INTEGRATION}

Fast growing educational technologies call for pre-service and in-service teachers to integrate ICT in teaching and learning. Institutions are developing continuous professional development programs to improve teachers' skills of ICT but still there are certain challenges which need proper planning and improvement strategies. Al-Senaidi, Lin, and Poirot (2009) supported the idea coined by Ertmer (1999); Snoeyink and Ertmer (2001), that there are two types of barriers: external which relate to lack of time and resources, limited technical support and unattended technical problems and internal which reflect teachers' attitudes such as lack of confidence, conservative attitude and poor knowledge of the benefits of technology.

Alev (2013) investigated ICT integration and possible challenges faced in pre-service teacher training programs. Some of the major challenges found were poor access to ICT tools, large classrooms, and lack of pedagogical and technical support. His study found class management, technical problems, poor ICT skills of teachers and learners, conservative attitude of the teachers about ICT use as further challenges in successful implementation of ICT. The study found a very poor level of ICT integration in teacher training programs (Maddux, 1994). A very limited use of ICT tools restricted to web browsing and word processing was another major barrier to ICT integration. Among the most challenging issues for ICT integration was lack of time to cover 
syllabus and use ICT appropriately. The contradiction of opinions between the teachers and student-teachers was found as another impediment for integrating ICT into teacher training programs. Most of the learners had no other option but to follow the trainer and that was a very scarce use of ICT.

Al-Senaidi, Lin, and Poirot (2009) in their study "Barriers to adopting technology for teaching and learning in Oman" found teachers' confidence, access to ICT, inappropriate training, lack of time to use technology properly, technical faults as serious determinants to ICT integration (Becta, 2004). These researchers further noticed that the teachers who were least ready to accept the change often failed to integrate ICT to meet the challenges. These teachers could not include technology into their teaching because they never realized the advantages of using ICT. AlSenaidi, Lin, and Poirot (2009) agree with Becta (2004) that gender issues also hinder ICT integration because Becta (2004) found that male teachers were more ready to use technology than females. Becta (2004) also observed that female teachers showed more anxiety with technology.

Using the categorization of ICT barriers coined by Veen (1993), the researchers found certain barriers at two distinct levels that is individual as well as institutional level. There are barriers which impact teachers at individual level such as lack of time and access to technology, technical problems and very poor quality ICT training. When thy observed teachers at institutional level, they observed lack of time and confidence, traditional attitude to teaching and poor understanding of the advantages of technology were some of the most common barriers (Veen, 1993). Lack of time is a common barrier which is at both individual and institutional levels.

Al-Senaidi, Lin, and Poirot (2009) found a direct and close relationship among various barriers which was initially observed by Ermter (1999). For example, if the teachers have limited access to technology or they face technology problems or are not properly trained in technology, they are likely to lose confidence in ICT integration. Though ICT integration is showing promising results in Omani higher education system (Al Khawaldi, 2000), yet it needs to improve proper utilization and comprehensive training of the teachers. The teachers' resistance to use technology in teaching is attributed to poorly designed software, doubt about the positive impact and benefits of technology, fear of technology and unsatisfactory staff professional development.

Huong Thi Bao Dinh (2015) analyzed the barriers to ICT integration as pointed by Ertmer, Addison, Lane, Ross and Woods, 1999; the British Educational Communications and Technology Agency-(BECTA), 2004). The researcher found that most of the barriers were extrinsic to the teachers. Dinh found insufficient I.T. sources for teachers, outdated software, lack of time for lesson preparation using ICT and very inadequate support from technical and administrative sides (Ertmer et al., 1999, p. 54). Dinh further analyzed the intrinsic barriers of teachers found by Ertmer el al. (1999). These barriers are attitudes and beliefs to technology, ICT integrated teaching and unwillingness to change (Semple, 2000; Yocum, 1996). The intrinsic barriers were worse than the extrinsic ones (BECTA, 2004; Ertmer el al., 1999; Park \& Son, 2009). The poor classroom organization often impedes teachers' use of technology. This impact varied according to teachers' beliefs about technology, that is either they used technology to support their teaching or to supplement the curriculum.

BECTA (2004) analyzed barriers to ICT integration at very deep levels. Lack of access to resources are further analyzed as lack of hardware, poor use of sources, outdated software and lack of teachers' personal access to computers (Shin \& Son, 2007; Yutdhana, 2004). Teachers' unwillingness to adapt change is believed to be due to unfamiliar equipment and poor teacher training. Huong Thi Bao Dinh agreed with BECTA (2004) that the lack of teachers' confidence 
was due to poor access to technology both in class and home (Parilah Md. Shah, 2015); poor knowledge to tackle technical problems; fear of making mistakes and poor ICT skills of teachers caused due to lack of training for both technology and pedagogy, shortage of time, negative attitude of colleagues about ICT integration, time required to learn ICT use and I.T. certificate (Salehi \& Salehi, 2013). Lack of hardware and inappropriate software causes poor access to technology (BECTA, 2004, p. 22; Sanders \& Morrison, 2001).

Hew and Brush (2007) in their research found the same barriers and causes; and grouped them into six categories "resources, institution, subject culture, attitudes and beliefs, knowledge and skills and assessment" but they were of the view that lack of time was not a barrier because it is teacher's ability to use technology in teaching (Mumtaz, 2000; Nyambane and Nzuki, 2014). Huong Thi Bao Dinh (2015) in his findings discusses Hew and Brush (2007) who attribute teachers' beliefs and attitudes to poor technology integration in teaching. Yildiz (2007) has almost the same findings about barriers to ICT integration, but he has classified the barriers into physical - poor hardware and software, poor resources for infrastructure and low quality internet connection-, educational - teacher's resistance and doubts concerning the benefits of ICT integration- and philosophical - misconceptions of the administration about ICT integration and its outcomes. He further points out that investing in computers is not a guarantee to successful ICT integrated teaching and learning because the institution, still has to invest more on teacher training, hiring technological staff and providing for regular I.T. support and upgrading. A poor investment in these things causes a failure to achieve the desired targets.

Another research categorized ICT inhibitors into the Context that is school, the Innovator that is teacher, the Innovation that is project, and the Operator that is student (Groff \& Mouza, 2008). The researchers concluded that teachers could directly resolve these barriers if they are trained properly and implementation of practical measures by administration. Lack of peer support is another serious barrier (Groff \& Mouza, 2008). Hew and Brush (2007) agreed supported Groff and Mouza (2008) in their findings that students' attitudes and beliefs; poor knowledge of technology and lack of interaction with technology were barriers to ICT integration. Mumtaz (200) suggested that if the institution doesn't give teachers proper time to learn and use ICT, teachers would show a negative attitude to ICT integrated teaching. The researcher found that lack of teachers' enthusiasm for ICT use would impede their interest in learning technology.

Nyambane and Nzuki (2014) called all barriers interdependent. For example, lack of time restricts the use of ICT (Abu Jaber \& Osman, 1996; Al Khawaldi, 2000; Al Musawi, 2002; Bialo \& Soloman, 1997; Boyd, 1997; Gibson \& Oberg, 2004; Kook, 1997; Wood et al., 2005; Vrasidas \& Glass, 2005); lack of proper teacher training impedes teachers' use of available resources. These researchers concluded that if the teachers lack confidence, competence and accessibility to use technology, they might not be able to adapt to change. Steiner and Mendelovitch (2016) regarded teachers' age and seniority as serious inhibitors (Hung \& Hsu, 2007). They found that the older teachers are less willing to adapt change by integrating ICT in teaching. The teachers who did not use internet were less willing to ICT integration (Beck, 1999). Steiner and Mendelovitch, (2016) pointed out that ICT integration sometimes produced fear in teachers' minds (Magen-Nagar \& Peled, 2012).

Many researchers (e.g. Wood et al., 2005) have called limited availability of technology and internet is highly potential barrier. Leliani, Agustiani, and Maryani ((2005) in their research findings agreed with Robinson (2003) in that teachers' personal characteristics like age, gender, teaching experience impede ICT integration. They further found that female teachers are less ready to use ICT because of poor access, skills and interest (Volman \& van Eck, 2001). Certain studies on teacher's experience and age found that more experienced as well as aged teachers 
were not reluctant to use ICT in their teaching (Van Braak et al., 2004) rather they preferred traditional ways of teaching.

Teacher's poor computer knowledge (Bingimals, 2009), lack of confidence (Robinson, 2003; Snoeyink \& Ertmer, 2001) and willingness to adatp ICT in their classes (Inan \& Lowther, 2010) were also found to be serious inhibitors. Leliani, Agustiani, and Maryani ((2005) agree with Gunter (2001) that many teacher training programs are not training teachers for skillful use of ICT in teaching. In his study, Fahad Salim Al-Adi found that teachers were overloaded with work and also obliged to finish the book within specified time; and hence couldn't use ICT in their teaching. The researcher in the words of Watson (2006) believes that the majority of the teachers are not reluctant to improve their ICT skills. Poor infrastructure (Gibson \& Oberg, 2004; Hill et al., 2005; Martins et al., 2004; Yutdhana, 2004), lack of time (Gibson \& Oberg, 2004), insufficient and unsatisfactory pre-service and in-service teacher training (Al-Huneini, 2006), the motivational support from management (Martins et al., 2004) are some barriers in ICT integration.

Opati (2013) found that the disproportionate ratio between students and students impeded ICT proper use. Only those teachers used technology that had no other option but to integrate ICT in their curriculum. In certain subjects' curriculum, the researcher found no use of ICT in teaching and learning. The students using technology confirmed that they used it for their assignments back at homes. Opati agrees with Clark (1983) and Weick (2000) that lack on inter-faculty collaboration and support hindered ICT integration. Kreutz and Rhodin (2016) found students' lack of accessibility leading to the lack of confidence, poor self-esteem and anxiety as a serious challenge in using ICT (Dörnyei, 2001; Pintrich et al., 1991).

\section{ADVANTAGE AND BENEFITS OF ICT INTEGRATION}

Technology is shaping education in innovative ways. Internet is helping the teachers and learners in enhancing all language skills (Houcine, 2011). Various softwares and applications have made learning and teaching a great pleasure. Classes are no more controlled by teachers rather have become student-centered. In the very recent years, virtual reality and artificial intelligence technologies are being integrated into teaching and learning.

Isisag (2012) in his study found that technology is a store house of knowledge and information for both teachers and learners. It helps leaners and teachers use online material and align it with their academic needs. Another very important blessing of technology is to facilitate the leaners and teachers in combining basic skills and using them for their specific lessons. For example, image and text can be mixed to teach reading and/or writing (Padurean \& Margan, 2009). Houcine (2011) explored the positive impacts of ICT that technology integration boosts teachers' interest in lessons and enhances learners' engagement. Korkut further found that technology helps the teachers focus on specific aspects of a lesson such as vocabulary, grammar, translation etc. Technology helps teachers use various contents unlike the textbooks where they are bound to follow the printed content material (Padurean \& Margan, 2009).

Korkut (2012) explored the role of technology in feedback process. Before the integration of technology into education, giving and/or writing comments on students' work has always been a challenge and painstaking task for most of the teachers. Various feedback tools introduced by technology have facilitated the feedback and error analysis and correction methods (Kumar \& Tammelin, 2008; Padurean \& Margan, 2009). The researcher further stated that technology has helped the teachers to adjust their lessons to meet the learners' needs. Web technology provides learners opportunities for peer learning. Korkut (2012) agrees with Kumar (2008) that 
technology has made it possible for teachers to give leaners individual feedback and guidance. It has enhanced teaching as well as learning in many more ways. Kumar further found that the integration of ICT is the best way to learn language communication skills (McLuhan, 2012).

Korkut (2012) has further explored that internet has made language learning possible without facing the challenges of travelling. The learners can now enjoy learning while staying at their home. Time constraint has always been a serious learning issue in the past. Technology has changed the situation in a positive direction. Today, learners can access any lesson anytime, anywhere. Online technology has facilitated the learners to repeat any lessons until they get mastery. Unlike the traditional learning system, ICT integrated education system has a 24/7 accessibility. ICT integration has improved teaching and learning methods by removing the barriers of time and place (McLuhan, 2012).

Sharing of knowledge, information, audio, video and even larger data has been materialized with the help of technology integration. Collaborative writing is another great miracle of technology in education. This way, technology has helped create academic environment where authentic material is incorporated into course material (Padurean \& Margan, 2009). Technology integration helps learners share difficulties in learning and knowledge through various blogs and communication channels and helps them learn language in direct contact with local culture (Padurean \& Margan, 2009; Rozgiene, Medvedeva, \& Straková, 2008). Isisag (2012) summarizes the finding of Houcine (2011) explaining the advantages of ICT. Technology motivates learners and engages them in learning. Students feel independence in learning through ICT integration. Above all, the ICT integration helps learners attain their course outcomes (Kirubahar, Subashini, \& Santhi, 2011). Technology has revolutionized pedagogical environment and has made collaborative learning a reality (Kumar \& Tammelin, 2008).

Isisag (2012) agrees with Salehi and Salehi (2012) that attending online workshops, seminars, and symposium as well as training sessions has helped teachers enhance their skills. Blended learning has promoted collaborative learning among students as well as teachers. Teachers have many opportunities to improve their skills. Mullamaa (2010) found that technology integration has increased students' motivation as they learn using various instructional strategies and teachers are using varied authentic ways of assessments (Houcine, 2011). Korkut agrees with Ramirez (2012) that Web 2.0 tools have provided students free access to online libraries and sources (Houcine, 2011). They can develop and create new material and share it with peers using web 2.0 tools (Luan et al., 2005)

Leliani, Agustiani and Maryani (2014) made research on various modes and forms of online technologies such as YouTube, Facebook, internet and smartphones and other portable devices. They found most of these highly useful for teachers as well as leaners. Some tools help teachers develop and design various language-teaching activities. These activities inculcate encouragement and motivation among learners (Davis, 2006). The researchers found that ICT tools provide material to meet the needs of the modern learners. Current information and news enrich the knowledge of both teachers and learners (Bell, 2005). Houcine (2011) believes that technology has made it possible for teachers to combine basic skills such as images, video and audio clips, texts etc. in their lessons. This has helped learners get the latest knowledge in an engaging style. Pronunciation has long been a challenge for the second language learners to master but thanks to technology that today a lot of online soft wares and programs such as google translation have resolved the issue.

Al-Adi supports Godwin-Jones (2003) and Salaberry (2001) that technology increases mutual interactions between students as well as student and teacher. Technology has removed the traditional limitations of access to material and poor sharing by providing immediate learning 
and fast sharing (Luan et al., 2005). Online teaching and learning has increase learners' motivation and engagement leading to better understanding (Suh, 2005). Fahad found that technology exposes teachers and learners to different cultures and backgrounds and increases their understanding about distant cultures (Lock \& Redmond, 2006). ICT integration has increased the important skills of electronic literacy and therefore, teachers and learners use internet more frequently for their information and relevant material.

Use of internet has improved the critical thinking and understanding in the field of research. The use of reliable and valid material was a great challenge before the advent of technology (Shetzer $\&$ Warschauer, 2000). Internet helps teachers and students to get published (Lee, 2000; Singhal, 1997) in digital format. Fahad Salim Al-Adi argues that plagiarism tools have promoted creativity and innovation in material developing and creation. The archive technology has provided platform for recording, reflecting on and refining one's work. It has boosted the accuracy and intelligibility of written and spoken communication (Greenfield, 2003; Jepson, 2005). Technology has helped reduce some of the serious issues of race, gender, handicap, accent and social status to minimal level (Shetzer \& Warschauer, 2000). Fahad Salim Al-Adi seconds Coppola (2004) that technology is now vital to educational reforms.

\section{GAPS/LIMITATIONS FOUND IN THE STUDIES REVIEWED}

All the 23 articles focused various areas of English language learning and teaching at various levels but there is very rare research on teacher training programs. Most of the research could not measure ICT integration levels in pre-service and in-service teacher training programs. Another important weak point is that most of the studies have focused individual areas such as barriers to ICT integration, advantages of ICT integration and teachers' and learners perception. There has been no important research exploring the relationship between teachers' beliefs and the variables involved. Researchers have not done any worth-mentioning work to find solutions to the problems related to ICT integration. No study has been conducted in Oman to measure the level of ICT knowledge between pre-service and in-service teachers. Moreover, no specific study has tried to explore the barriers to ICT integration faced by students, teachers, administrators and policy-makers simultaneously.

\section{POSSIBLE DIRECTIONS FOR FUTURE RESEARCH AND SCOPE FOR ICT INTEGRATION IN TEACHER TRAINING PROGRAMS IN OMAN}

ICT integration changes the traditional ways of teaching and learning. It motivates teachers and learners to adapt technology and modify teaching material and strategies to meet the needs of the day (Reid, 2002). If ICT is integrated using diverse teaching and learning methods and techniques, especially constructive methods, learners will be able to achieve learning outcomes. This requires future researchers to explore the barriers to ICT integration and find practical solutions leading to advantages of technology in teaching and learning.

Educational research and most importantly qualitative content analysis have a very short record in Oman. Intensive research is required to focus teachers' perceptions, barriers to ICT integration and benefits of this integration. Most of the research done in Oman is restricted to one and the only public university, namely Sultan Qaboos University. There is the need to explore the role of ICT at national levels. Very nominal research has focused higher education institutions in Oman. Vocational training institutes - both public and private, private colleges, public Applied Sciences and Technology colleges are using latest educational technology such as smart boards, Moodle and a lot more but no worth mentioning research has been conducted to 
explore the use of technology in these institutions. This research will definitely boost up the impact and awareness of technology in Omani education system.

The research findings are likely to provide tangible suggestions and guidelines for future researchers. These findings are almost likely to help the institutions and concerned bodies to design curriculum for teacher training programs with maximum ICT integration. It will further help the institutions prepare teachers with comprehensive knowledge of technology implementation in teaching and learning. This research may also explore the resonance between teachers' attitudes and their practices in using technology in their student-teacher programs.

\section{REFERENCES}

Abu Jaber, M., \& Osman, M. (1996). Utilization of instructional technology services by faculty members at Sultan Qaboos University. In International Yearbook on Teacher Education (ICET): 1996 proceedings (Vol. 2, pp. 13-21). Amman, Jordan.

Al Khawaldi, H. (2000). Faculty perceptions towards ET status at Omani colleges of education (Unpublished MA thesis), Yarmouk University, Jordan. https://doi.org/10.1007/s11423007-9041-x

Al Musawi, A. (2002). Existing formats and functions of media units in the Omani higher education. Journal of Educational and Psychological Sciences, Bahrain University, 3(2), 3351. https://doi.org/10.12785/JEPS/030206

Albirini, A. (2006). Teachers' attitudes toward information and communication technologies: The case of Syrian EFL teachers. Computers \& Education, 47(4), 373-398. https://doi.org/10.1016/j.compedu.2004.10.013

Al-Huneini, H. (2006). Training teachers to teach using computers in Ibra Basic Education Schools (Unpublished MA ICT \& Education Dissertation). School of Education, University of Leeds.

Al-Sadi, F. S. (2003). The Internet in English language teaching in Oman, 187-201. https://doi.org/10.4018/JCIT.2016010104

Al-Senaidi, S. R., \& Gawande, V. (2013). Factors affecting adoption of ICT among Omani faculty members in Sultanate of Oman. International Journal of Computing Academic Research (IJCAR), 2(5). Retrieved from http://meacse.org/IJCAR/archives/31.pdf

Al-Senaidi, S., Lin, L., \& Poirot, J. (2009). Barriers to adopting technology for teaching and learning in Oman. https://doi.org/10.1016/j.compedu.2009.03.015

Bialo, E., \& Soloman, G. (1997). Open your eyes: The evidence is there! Technology and Learning, 18, 70-71. https://doi.org/10.1007/s11423-007-9041-x

Bingimlas, K. A. (2009). Barriers to the successful integration of ICT in teaching and learning environments: A review of literature. Eurasia Journal of Mathematics, Science and Technology Education, 5(3), 235-245. https://doi.org/10.12973/ejmste/75275

Boyd, E. (1997). Training-on-demand: A model for technology staff development. Educational Technology, 37, 46-49. https://doi.org/10.1007/s11423-007-9041-x

Castro Sánchez, J. J., \& Alemán, E. C., 2011. Teachers' opinion survey on the use of ICT tools to support attendance-based teaching. Journal Computers and Education, 56, 911-915. https://doi.org/10.1016/j.compedu.2010.11.005 
Chang, Q., \& Zhao, S. (2011). Pedagogical Reasoning on the Integration of ICT and English Teaching. In 2011 International Conference on Modeling, Simulation and Control. IPCSIT 10. Retrieved from http://www.ipcsit.com/vol10/21-ICMSC2011S10007.pdf

Clark, W., \& Luckin, R. (2013). What the research says. iPads in the classroom. London: Institute of Education University of London. Retrieved from https://digitalteachingandlearning. files.wordpress.com/2013/03/ipads-in-the-classroom-report-lkl.pdf

Coppola, E. (2004). Powering up: Learning to teach well with technology. New York: Teachers' College Press. Retrieved from https://catalog.libraries.psu.edu/catalog/2759507

Cuban, L. (2001). Oversold and underused: Computers in the classroom. London: Harvard University Press. https://doi.org/10.12691/education-2-9-4

Dang, X. T., Nicholas, H., \& Lewis, R. (2012, January). Key barriers to ICT uptake in foreign language teaching in Vietnam: A case study. Paper presented at the International Technology, Education and Development Conference, Valencia, Spain. Retrieved from https://www.researchgate.net/publication/265090672_ICT_in_foreign_language_teachi ng_in_an_innovative_university_in_Vietnam_Current_practices_and_factors_affecting_ ICT_use

Dinh, H. T. B. (2015). Factors influencing English as a Foreign Language (EFL) teachers' use of Information and Communication Technology (ICT) in classroom practice: A mixed methods study at Hanoi University, Vietnam (Doctoral Thesis). Australia: The Royal Melbourne Institute of Technology. Retrieved from www.camtesol.org/Publication/Selected_ Papers_Vol.5_2009.pdf

Dinh, T. B. H. (2009, February). Factors affecting novice EFL teachers' adoption of ICT in classroom practice. Paper presented at the CAMTESOL 5th, Phnom Penh. Retrieved from www.camtesol.org/Publication/Selected_Papers_Vol.5_2009.pdf

Dörnyei, Z. (2001). Motivational Strategies in the language classroom. Cambridge University Press. https://doi.org/10.1017/CBO9780511667343

Ertmer, P. A., Gopalakrishnan, S., \& Ross, E. M. (2001). Technology-using teachers: comparing perceptions of exemplary technology use to best practice. Journal of Research on Technology in Education, 33(5). Retrieved from http://www.iste.org/jrte/33/5/ertmer.cfm

Frydrochov Klimova, B., \& Poulova, P. (2014). ICT as a motivational tool in the learning of foreign languages. Retrieved from http://www.europment.org/library/2014/interlaken/ bypaper/EDU/EDU-06.pdf

Gibson, S., \& Oberg, D. (2004). Visions and realities of internet use in schools: Canadian Perspectives. British Journal of Educational Technology, 35(5), 569-585. https://doi.org/10.1111/j.0007-1013.2004.00414.x

Graham, R. C., Burgoyne, N., Cantrell, P., Smith, L., St Clair, L., \& Harris, R. (2009). Measuring the TPACK confidence of inservice science teachers. TechTrends, 53(5), 70-79. https://doi.org/10.1007/s11528-009-0328-0

Gray, K. C. (2001). Teachers' perceptions of innovation adoption. Action in Teacher Education, 23(2), 30-35. https://doi.org/10.1080/01626620.2001.10463061

Groff, J., \& Mouza, C. (2008). A framework for addressing challenges to classroom technology use. AACE Journal, 16(1), 21-46. 
Gunter, G. A. (2001). Making a difference: using emerging technologies and teaching strategies to restructure an undergraduate technology course for pre-service teachers. Education Media International, 38(1), 13-20. https://doi.org/10.1080/09523980010021190

Haney, J. J., Lumpe, A. T., Czerniak, C. M., \& Egan, V. (2002). From beliefs to actions: The beliefs and actions of teachers implementing change. Journal of Science Teacher Education, 13, 171-187. https://doi.org/10.1023/A:1016565016116

Hasselbring, T. S., Smith, L., Glaser, C. W., Barron, L., Risko, V., Snyder, C., et al. (2000). Literature review: Technology to support teacher development. Washington, DC: National Partnership for Excellence and Accountability in Teaching (ERIC Document Reproduction Service No. ED448159). https://doi.org/10.5296/jse.v2i2.1174

Hew, K. F., \& Brush, T. (2007). Integrating technology into K-12 teaching and learning: Current knowledge gaps and recommendations for future research. Educational Technology Research and Development, 55, 223-252. https://doi.org/10.1007/s11423-006-9022-5

Higgins, S., \& Moseley, D. (2001). Teachers' thinking about information and communications technology and learning: beliefs and outcomes. Teacher Development, 5(2), 191-210. https://doi.org/10.1080/13664530100200138

Hill, J., Reeves, T., Grant, M., Han, S., \& Wang, S. (2005). Learning in a wireless environment. The success and challenges of ubiquitous computing in a school. In C. Vrasidas, G. Vrasidas, \& G.V. Glass (Eds.). Preparing teachers to teach with technology. Greenwich: Information Age Publishing.

Houcine, S. (2011). The effects of ICT on learning/teaching in a foreign language. Retrieved from http://www.pixel-online.net/ICT4LL2011/common/download/Paper_pdf/IBL69-437-FPHoucine- ICT4LL2011.pdf

Howard, B. C., McGee, S., Schwartz, N., \& Purcell, S. (2000). The experience of constructivism: Transforming teacher epistemology. Journal of Research on Computing in Education, 32, 455-465. https://doi.org/10.1080/08886504.2000.10782291

Hsu, Y. C., Hung, J. L., \& Ching, Y. H. (2013). Trends of educational technology research: More than a decade of international research in six SSCl-indexed refereed journals. Educational Technology Research and Development, 61(4), 685-705. https://doi.org/10.1007/s11423013-9290-9

Inan, F. A., \& Lowther, D. L. (2010). Factors affecting technology integration in K-12 classrooms: a path model. Education Tech Research Dev, 58(2), 137-154. https://doi.org/10.1007/s11423-009-9132-y

Isisag, K. U. (2012). The Positive Effects of Integrating ICT in Foreign Language Teaching. International Conference "ICT for Language Learning" 5th Edition (2012) (pp. 1-4). Florence, Italy: Pixel. Retrieved from https://conference.pixel-online.net/conferences/ ICT4LL2012/common/download/Paper_pdf/235-IBT107-FP-Isisag-ICT2012.pdf

Jedeskog, G. (1998). Datorer, IT och en förändrad skola. Lund: Studentlitteratur. Retrieved from https://www.bokus.com/bok/9789144008363/datorer-it-och-en-forandrad-skola/ 
Kılıçkaya, F., \& Seferoğlu, G. (2013). The impact of CALL instruction on English language teachers' use of technology in language teaching. Journal of Second and Multiple ..., 20-38. Retrieved from http://journal.science-res.com/index.php?journal=JSMULA\&page=article \&op=view\&path[]=3

Kirubahar, J. S., Subashini, A., \& Santhi, V. J. (2011). ICT Enabled Language Learning Using Handphones - An Experimental Study. Language in India, Strength for Today and Bright Hope for Tomorrow, 11.

Koh, J. H. L., Woo, H. L., \& Lim, W. Y. (2013). Understanding the relationship between Singapore preservice teachers' ICT course experiences and technological pedagogical content knowledge (TPACK) through ICT course evaluation. Educational Assessment, Evaluation and Accountability, 25(4), 321-339. https://doi.org/10.1007/s11092-013-9165-y

Kook, J. (1997). Computers and communication networks in educational settings in the twentyfirst century: Preparation for educator's new roles. Educational Technology, 37(2), 56-60.

Kumar, S., \& Tammelin, M. (2008). Integrating ICT into Language Learning and Teaching: Guide for Institutions. Johannes Kepler Universität Linz, Altenberger Straße 69, 4040 Linz. Retrieved from https://www.academia.edu/235896/Kumar_S._and_Tammelin_M._2008 _._Integrating_ICT_into_Language_Learning_and_Teaching_A_Guide_for_European_Ins titutions._Linz_Austria_Johannes_Kepler_Universit\%C3\%A4t

Lee, K. (2000). Energizing the ESL/EFL classroom through internet activities. The Internet TESL Journal, April 2000. Retrieved from http://iteslj.org/Articles/Lee-InternetActivities.html

Leliani, S., Agustiani, M., \& Maryani, L. (2014). Integrating ICT to EFL Classroom. Sriwijaya University Learning and Education-International Conference May 16-18, 2014. Palembang, Indonesia: Faculty of Teacher Training and Education, Sriwijaya University. https://doi.org/10.21831/cp.v38i1.23439

Li, G., \& Ni, X. (2011). Primary EFL teachers' technology use in China: Patterns and perceptions. RELC Journal, 42(69), 69-85. https://doi.org/10.1177/0033688210390783

Lock, J., \& Redmond, P. (2006). International on-line collaboration: Modeling on-line learning and teaching. MERLOT Journal of On-line Learning and Teaching, 2(4), 233-247. Retrieved from https://jolt.merlot.org/vol2no4/lock.pdf

Lowther, D. L., Inan, F. A., Strahl, J. D., \& Ross, S. M. (2008). Does technology integration work when key barriers are removed? Educational Media International, 45, 195-213. https://doi.org/10.1080/09523980802284317

Maddux, C. (1994). Integration is the Only Option We have. Journal of Information Technology for Teacher Education, 3(2), 129-133. https://doi.org/10.1080/0962029940030201

Magen-Nagar, N., \& Peled, B. (2012). Me'afyenei Morim BaSvivah Limudit Metukshevet [Characteristics of Israeli school teachers in computer-based learning environments]. Chais Conference for Instructional Technologies Research: Learning in the Technological Era (pp. 212-221). Raanana: Open University._https://doi.org/10.12973/eurasia.2017. 00670a

Martins, C. B. M. J., Steil, A. V., \& Todesco, J. L. (2004). Factors influencing the adoption of the internet as a teaching tool at foreign language schools. Computers and Education, 42, 353374. https://doi.org/10.1016/j.compedu.2003.08.007 
McCrory, R. A. V. E. N. (2008). Science, technology, and teaching: The topic-specific challenges of TPCK in science. Handbook of technological pedagogical content knowledge (TPCK) for educators, 193-206. Retrieved from https://www.punyamishra.com/2008/01/14/ handbook-of-tpck/

McLuhan, M. (2012). Web 2.0 and English Language Learning: A New Model or A New Muddle? Retrieved from http://blog.englishcentral.com/2012/08/04/web-2-0-and-language-learn ing/

Md. Shah, P., \& L. Empungan, J. (2015). ESL Teachers' Attitudes towards Using ICT in Literature Lessons. International Journal of English Language Education, 3(1), 201. https://doi.org/10.5296/ijele.v3i1.7158

Mendieta Aguilar J. (2012). Blended Learning and the Language Teacher: [A Literature Review] (pp. 163-180). Bogotá, Colombia. https://doi.org/10.14483/udistrital.jour.calj.2012.2.a10

Mullamaa, K. (2010). ICT in Language Learning - Benefits and Methodological Implications. International education studies, 3(1). https://doi.org/10.5539/ies.v3n1p38

Mumtaz, S. (2000). Factors affecting teachers' use of information and communication technologies: A review of the literature. Journal of Information Technology for Teacher Education, 9(3), 319-342. https://doi.org/10.1080/14759390000200096

Nedim ALEV (2003). Integrating information and communications technology (ICT) into preservice science teacher education: the challenges of change in a Turkish faculty of education (Doctoral Thesis). United Kingdom: University of Leicester.

Nyambane, C. O., \& Nzuki, D. (2014). Factors influencing ICT integration in teaching - A literature review. International Journal of Education and Research, 2(3), 1-17.

Opati, O. D. (2013). The Use of ICT in Teaching and Learning at Makerere University. The Case of College of Education and External Studies. University of Oslo, 1-102. Retrieved from http://urn.nb.no/URN:NBN:no-38128

Pachler, N. (2001). Connecting schools and pupils: To what end? Issues related to the use of ICT in school-based learning, In M. Leask (ed.) Issues in teaching using ICT (pp. 15-30). London: Routledge Falmer. https://doi.org/10.4324/9780203185117-2

Padurean, A., \& Margan, M. (2009). Foreign Language Teaching Via ICT. Revista de Informatica Sociala, VII(12). Retrieved from http://citeseerx.ist.psu.edu/viewdoc/download? doi=10.1.1.617.7233\&rep=rep1\&type=pdf

Park, C. N., \& Son, J-B. (2009). Implementing computer assisted language learning in the EFL classroom: Teachers' perceptions and perspectives. International Journal of Pedagogies \& Learning, 5(2), 80-101. https://doi.org/10.5172/ijpl.5.2.80

Pintrich, P. R., Smith, D. A. F., Garcia, T., \& McKeachie, W. J. (1991). A manual for the use of the Motivated Strategies for Learning Questionnaire (MSLQ). Ann Arbor: University of Michigan, National Center for Research to Improve Postsecondary Teaching and Learning.

Pourhosein Gilakjani, A. (2012). EFL Teachers' Beliefs toward Using Computer Technology in English Language Teaching. Journal of Studies in Education, 2(2), 62-80. https://doi.org/10.5296/jse.v2i2.1174 
Prensky, M. (2001). Digital natives, digital immigrants. On the Horizon, 9(1), 1-2. https://doi.org/10.1108/10748120110424816

Qureshi, Q. A., Nawaz, A., \& Khan, N. (2011). Prediction of the problems, user-satisfaction and prospects of e-learning in HEls of KPK, Pakistan. International Journal of Science and Technology Education Research, 2(2), 13-21. Retrieved from http://www.academicjournals.org/IJSTER

Rahimi, M., \& Yadollahi, S. (2011). ICT Use in EFL Classes: A Focus on EFL Teachers' Characteristics. World Journal of English Language, 1(2), 17-30. https://doi.org/10.5430/wjel.v1n2p17

Reid, S. (2002). The integration of ICT into classroom teaching. Research in Ontario Secondary Schools, 7(1). Retrieved from http://www.oise.utoronto.ca/field-centres/TVC/Ross Reports/vol7no1.htm

Reyes Jr, V. C., Reading, C., Doyle, H., \& Gregory, S. (2017). Integrating ICT into teacher education programs from a TPACK perspective: Exploring perceptions of university lecturers. Computers \& Education, 115(2017), 1-19. https://doi.org/10.1016/j.compedu.2017.07. 009

Rhodin, N., \& Kreutz, J. (2016). Degree Project in English and Learning the influence of ICT on learners' motivation towards learning English. Retrieved from https://muep.mau.se/ bitstream/handle/2043/20747/Degree\%20Project\%20Josefin\%20\&\%20Natalie.pdf?sequ ence $=2$

Robinson, W. I. (2003). External, and internal factors which predict teachers' computer usage in K-12 classrooms. Detroit, MI: Wayne State University. Retrieved from https://dl.acm.org/citation.cfm?id=1087223

Rozgiene, I, Medvedeva, O., \& Straková, Z. (2008). Integrating ICT into Language Learning and Teaching: Guide for Tutors. Johannes Kepler Universität Linz, Altenberger Straße 69, 4040 Linz. Retrieved from https://www.academia.edu/2454849/Integrating_ICT_into_ Language_Learning_and_Teaching

Saglam, A. L. G., \& Sert, S. (2012). Perceptions of in-service teachers regarding technology integrated English language teaching. Turkish Online Journal of Qualitative Inquiry, 3(3), 1-14. https://doi.org/10.1080/08886504.2001.10782313

Salehi, H., \& Salehi, Z. (2012). Integration of ICT in language teaching : Challenges and barriers. 3rd International Conference on E-Education, e-Business, e-Management and e-Learning, 27, 215-219.

Sanders, D. W., \& Morrison-Shetlar, A. I. (2001). Student attitudes toward web-enanced instruction in an introductory biology course. Journal of Research on Computing in Education, 33(3), 251-262. https://doi.org/10.1080/08886504.2001.10782313

Saye, J. W. (1998). Technology in the classroom: The role of disposition in teacher gatekeeping. Journal of Curriculum and Supervision, 13(3), 210-234.

Scrimshaw, P. (2004). Enabling teachers to make successful use of ICT. [Review of BECTA Literature]. Becta ICT Research, Version 1. Retrieved from https://dera.ioe.ac.uk/1604/1/becta_2004_enablingsuccessfuluse_litrev.pdf 
Selinger, M. (2001c). Information and Communication Technology in Schools. Retrieved from http://www.imfundo.org/papers/ict_in_s.doc/

Semple, A. (2000). Learning Theories and their Influence on the Development and Use of Educational Technologies. Australian Science Teachers Journal, 46(3), 21-28. Retrieved from http://www.hadassah.org.il/media/2173055/sempel.pdf

Shetzer, H., \& Warschauer, M. (2000). An electronic literacy approach to network- based language teaching. In M. Warschauer \& R. Kern (Eds.), Network-based language teaching: Concepts and practice (pp. 171-185). New York: Cambridge University Press. https://doi.org/10.1017/СB09781139524735.010

Shulman, L. S. (1987). Knowledge and teaching: Foundations of the new reform. Harvard Educational Review, 57(1), 1-22. https://doi.org/10.17763/haer.57.1.j463w79r56455411

Singhal, M. (1997). The internet and foreign language education: Benefits and challenges. The Internet TESL Journal, June 1997. Retrieved from http://iteslj.org/Articles/SinghalInternet.html

Snoeyink, R., \& Ertmer, P. (2001). Thrust into technology: How veteran teachers respond. Journal of Educational Technology Systems, 30, 85-111. https://doi.org/10.2190/YDL7-XH09RLJ6-MTP1

Steiner, D., \& Mendelovitch, M. (2017). "I'm the same teacher": The attitudes of science and computer literacy teachers regarding integrating ICT in instruction to advance meaningful learning. Eurasia Journal of Mathematics, Science and Technology Education, 13(5), 12591282. https://doi.org/10.12973/eurasia.2017.00670a

Suh, S. (2005). The effect of using guided questions and collaborative groups for complex problem solving on performance and attitude in a web-enhanced learning environment (PhD Dissertation). College of Education, Florida State University. Retrieved from http://etd.lib.fsu.edu/theses/available/etd-11102005-120503/

Troudi, S., \& A-Mahrooqi, R. (2014). Blended learning in Saudi Arabia: potential at the tertiary level. Using Technology in Foreign Language Teaching, 30-44. Retrieved from https://books.google.com/books?id=NeOmBgAAQBAJ\&pgis=1

Van Braak, J., Tondeur, J., \& Valcke, M. (2004). Explaining different types of computer use among primary school teachers. European Journal of Psychology of Education, 19(4), 407-422. https://doi.org/10.1007/BF03173218

Vannatta, R. A., \& Fordham, N. (2004). Teacher dispositions as predictors of classroom technology use. Journal of Research on Technology in Education, 36(3), 253-272. https://doi.org/10.1080/15391523.2004.10782415

Varsidas, C., \& Mclsaac, M. (2001). Integrating technology in teaching and teacher education: Implications for policy and curriculum reform. Educational Media International, 38(2/3), 127-132. https://doi.org/10.1080/09523980110041944

Veen, W. (1993). The role of beliefs in the use of information technology: Implications for teacher education, or teaching the right thing at the right time. Journal of Information Technology for Teacher Education, 2, 139-153. https://doi.org/10.1080/ 0962029930020203 
Volman, M., \& van Eck, E. (2001). Gender equity and information technology in education: The second decade. Review of Educational Research, 71(4), 613-634. https://doi.org/10.3102/00346543071004613

Vrasidas, C., \& Glass, G. (2005). Achieving technology integration in classroom teaching. In C. Vrasidas \& G. Glass (Eds.). Preparing teachers to teach with technology (pp. 1-22). Greenwich: Information Age Publishing.

Weert, T. V., \& Tatnall, A. (2005). Information and Communication Technologies and Real-Life Learning: New Education for the New Knowledge Society. New York: Springer. https://doi.org/10.1007/b136546

Weick K. E. (2000). Educational Organisations as Loosely Coupled Systems. In D. D. Dill (ed.), The Nature of Academic Organisation (pp. 125). Lemma Publishers.

Williams, M., \& Burden, R. (1997). Psychology for Language Teachers. Cambridge: Cambridge University Press

Wood, E., Mueller, J., Willoughby, T., Specht, J., \& Deyoung, T. (2005). Teachers' perceptions: Barriers and supports to using technology in the classroom. Education, Communication and Information, 5(2), 183-206. https://doi.org/10.1080/14636310500186214

Wood, E., Mueller, J., Willoughby, T., Specht, J., \& Deyoung, T. (2005). Teachers' perceptions: barriers and supports to using technology in the classroom. Education, Communication and Information, 5(2), 183-206. https://doi.org/10.1080/14636310500186214

Yang, S. C., \& Huang, Y. F. (2008). A study of high school English teachers' behavior, concerns and beliefs in integrating information technology into English instruction. Computers in Human Behavior, 24(3), 1085-1103. https://doi.org/10.1016/j.chb.2007.03.009

Yildiz, S. (2007). Critical issues: Limited-technology contexts. In J. Egbert \& E. Hanson-Smith (Eds.), CALL environment: Research, practice, and critical issues (2nd ed., pp. 145-159). Mattoon, Illinois: TESOL Inc.

Yocum, K. (1996). Teacher-Centered Staff Development for Integrating Technology into classrooms. Technology Horizons in Education, 24, 4.

Zhao, Y., \& Frank, K. A. (2003). Factors affecting technology uses in school: An ecological perspective. American Educational Research Journal, 40(4), 807- 840. https://doi.org/10.3102/00028312040004807

Correspondence: Kashif Ali Sabiri, University of Tampere, Finland.

E-mail: kashifalisabiri@hotmail.com 